UDC 330.15

LBC 65.28

\title{
ANALYSIS OF THE LEVEL AND QUALITY OF WATER SUPPLY STRATEGIES FOR SOCIO-ECONOMIC DEVELOPMENT OF THE REGIONS OF THE LOWER DON BASIN ${ }^{1}$
}

\author{
Natalya A. Kosolapova \\ Southern Federal University, Rostov-on-Don, Russian Federation \\ Ekaterina E. Aydarkina \\ Southern Federal University, Rostov-on-Don, Russian Federation
}

\begin{abstract}
The effectiveness and validity of regional strategy processes are to a significant extent determined by the results of analysis and accounting of available resources. The systematic deterioration of the environmental situation in the Russian Federation and the growth in the consumption of natural resources and the exploitation of natural objects raise the issues of objective and qualitative assessment of the degree of resources availability in the franes of existing regional development strategies.

The most acute problem for the world as a whole is the shortage of water resources, especially fresh water. This is due to the fact that the world's water consumption is increasing every day, and their use is extensive. To date, the shortage of fresh water is a limiting factor in the economic growth of a large number of countries.

The purpose of the paper is to compare the strategic tasks facing the regions included in the Lower Don basin system with the possibilities of their resource provision in terms of the volume and quality of available water resources. The research methodology is based on the theories of regional economy and regional management, resource-oriented approach to water management, rational water use.

It has been found that the long-term planning of the development of the country's regions takes place without assessing the required amount of natural resources and their quality characteristics, the main objectives of regional strategy of the studied areas, requiring an increase in the volume of use or load on water resources and facilities. Monitoring of the quality of water bodies in the Lower Don basin reveals the unsatisfactory conditions.

The conclusion is made about the low level of water availability and the existing shortage of water resources with their poor quality.
\end{abstract}

Key words: strategy of socio-economic development, region, water resources, water supply, quality of water, ecological state.

Citation. Kosolapova N.A., Aydarkina E.E. Analysis of the Level and Quality of Water Supply Strategies For Socio-Economic Development of the Regions of the Lower Don Basin. Vestnik Volgogradskogo gosudarstvennogo universiteta. Seriya 3, Ekonomika. Ekologiya [Science Journal of Volgograd State University. Global Economic ДЛЯ РЕАЛИЗАЦИИ СТРАТЕГИЙ СОЦИАЛЬНО-ЭКОНОМИЧЕСКОГО РАЗВИТИЯ РЕГИОНОВ БАССЕЙНА НИЖНЕГО ДОНА ${ }^{1}$

\author{
Наталья Алексеевна Косолапова
}

Южный федеральный университет, г. Ростов-на-Дону, Российская Федерация 


\section{Екатерина Евгеньевна Айдаркина}

Южный федеральный университет, г. Ростов-на-Дону, Российская Федерация

Аннотация. Эффективность и обоснованность процессов регионального стратегирования в существенной степени определяются результатами анализа и учета располагаемых ресурсов. Систематическое ухудшение экологической ситуации на территории Российской Федерации и рост объемов потребления природных ресурсов и эксплуатации природных объектов актуализируют вопросы объективной и качественной оценки степени ресурсообеспеченности имеющихся стратегий регионального развития.

Наиболее остро для мира в целом стоит проблема дефицита водных ресурсов, особенно пресной воды. Данное обстоятельство вызвано тем, что мировые объемы потребления водных ресурсов ежедневно увеличиваются, причем их использование носит экстенсивный характер. На сегодняшний день дефицит пресной воды выступает сдерживающим фактором экономического роста большого числа стран.

Цель статьи - сопоставить стратегические задачи, стоящие перед регионами, входящими в Нижнедонскую бассейновую систему, с возможностями их ресурсного обеспечения с позиций объема и качества доступных к использованию водных ресурсов. Методология исследования базируется на положениях теорий региональной экономики и регионального управления, ресурсно-целевого подхода к управлению водопользованием, рационального водопользования.

В процессе исследования было выяснено, что планирование развития регионов страны на долгосрочную перспективу происходит без оценки требуемого количества природных ресурсов и их качественных характеристик, были выделены основные задачи регионального стратегирования исследуемых территорий, требующие повышения объемов использования или нагрузки на водные ресурсы и объекты. Мониторинг качества водных объектов регионов бассейна Нижнего Дона позволил выявить, что оно оценивается как неудовлетворительное.

Сделан вывод о низкой водообеспеченности региональных стратегий и имеющемся дефиците водных ресурсов при неудовлетворительном их качественном состоянии.

Ключевые слова: стратегия социально-экономического развития, регион, водные ресурсы, водообеспеченность, качество водных ресурсов, экологическое состояние.

Цитирование. Косолапова Н. А., Айдаркина Е. Е. Анализ уровня и качества водообеспеченности для реализации стратегий социально-экономического развития регионов бассейна Нижнего Дона // Вестник Волгоградского государственного университета. Серия 3, Экономика. Экология. - 2018. - Т. 20, № 3. - С. 126138. - DOI: https://doi.org/10.15688/jvolsu3.2018.3.13

Актуальность рассмотрения вопросов рационального использования водных ресурсов на региональном уровне тесно коррелирует как с успешностью экономического развития в целом, с учетом стратегической важности водных ресурсов, так и с решением социальных и экологических проблем территорий. При этом взаимодействие экономических субъектов территории в сфере водопользования необходимо рассматривать в рамках отношений: региона, на территории которого располагается водный объект, как социально-экономической системы, использующей водные ресурсы; организаций, управляющих водохозяйственными системами бассейнов; государства, выступающего в качестве квазисобственника водных ресурсов; потребителей водных ресурсов.

В границах отдельных регионов государственная компонента потенциала регионального водохозяйственного комплекса «материализуется, во-первых, в специальной подсис- теме, содержащей информацию нормативнозаконодательного, распорядительного и т. д. характера, поступающую от соответствующих структур органов власти территории; вовторых, в принятии на себя государством части рисков, особенно когда оно выступает также в качестве соинвестора инновационных проектов; в-третьих, в предоставлении информации о потенциальных инвесторах или партнерах по инновационному бизнесу» [8].

Особую важность в этой связи приобретают вопросы согласования региональных и государственных интересов в сфере водопользования трансрегиональными водными объектами, что связано с необходимостью удовлетворения потребностей экономики и населения данных регионов в водных ресурсах и соблюдении экологических нормативов и требований в водопользовании. Трудность решения таких вопросов связана с тем, что зачастую требования, выдвигаемые регионами как участниками водохозяй- 
ственного комплекса, завышены и противоречивы с точки зрения водного объекта.

Как известно, основным документом, определяющим направления развития территории, является его стратегия, в которой с той или иной степенью детализации описаны основные цели, задачи и мероприятия, направленные на устойчивое развитие региональной социально-экономической системы. В то же время необходимо отметить, что в этом документе практически не рассматриваются вопросы ресурсного обеспечения данных мероприятий, в том числе водными ресурсами, но абсолютно понятно, что без определения доступных к использованию водных ресурсов решение поставленных задач невозможно.

В связи с этим авторами в данной статье сделана попытка сопоставить стратегические задачи, стоящие перед регионами, входящими в Нижнедонскую бассейновую сис- тему, с возможностями их ресурсного обеспечения с позиций объема и качества доступных к использованию водных ресурсов. По данным Донского бассейнового водного управления, регионами, относящимися к бассейну Нижнего Дона, являются: Ростовская область. Республика Калмыкия, Волгоградская область, Ставропольский край, Краснодарский край. В ходе исследования был проведен анализ стратегий социально-экономического развития данных регионов, выделены основные стратегические цели и задачи регионального развития. Результаты анализа представлены в таблице 1.

Как видно из данных таблицы 1, основными направлениями стратегического развития исследуемых регионов являются: повышение социального статуса и уровня жизни населения регионов; рост экономической конкурентоспособности за счет развития АПК, промыш-

Таблица 1

Цели и задачи стратегий развития регионов бассейна Нижнего Дона

\begin{tabular}{|c|c|c|}
\hline Регион & $\begin{array}{c}\text { Стратегические } \\
\text { цели }\end{array}$ & Задачи \\
\hline \multirow[t]{3}{*}{$\begin{array}{l}\text { Ростов- } \\
\text { ская об- } \\
\text { ласть }\end{array}$} & $\begin{array}{l}\text { 1. Повышение } \\
\text { конкурентоспо- } \\
\text { собности эконо- } \\
\text { мики области }\end{array}$ & $\begin{array}{l}\text { 1.1. Развитие ключевых комплексов и секторов экономики: } \\
\text { - агропромышленного и рыбохозяйственного; } \\
\text { - машиностроительного; } \\
\text { - металлургического производства; } \\
\text { - химического комплекса; } \\
\text { - легкой промышленности; } \\
\text { - добычи и переработки полезных ископаемых; } \\
\text { - строительного комплекса; } \\
\text { - сферы услуг, включая потребительский рынок, туристско-рекреационный ком- } \\
\text { плекс, финансово-банковский сектор; } \\
\text { - международных отношений и внешнеэкономической деятельности; } \\
\text { - малого и среднего предпринимательства; } \\
\text { - системы привлечения инвестиций. } \\
\text { 1.2. Инфраструктурное развитие: } \\
\text { - развитие транспортно-логистической инфраструктуры; } \\
\text { - развитие энергетической инфраструктуры, включая электроэнергетику и газифи- } \\
\text { кацию; } \\
\text { - развитие информационно-телекоммуникационной инфраструктуры и связи. } \\
\text { 1.3. Развитие сферы услуг. } \\
\text { 1.4. Снижение уровня дотационности }\end{array}$ \\
\hline & $\begin{array}{l}\text { 2. Пространст- } \\
\text { венное развитие } \\
\text { региона }\end{array}$ & $\begin{array}{l}\text { 2.1. Развитие Ростовско-Шахтинской конурбации, Волгодонской системы расселе- } \\
\text { ния и приграничных территорий Ростовской области в рамках Еврорегиона «до- } \\
\text { басс». } \\
\text { 2.2. Повышение устойчивости системы расселения региона. } \\
\text { 2.3. Снижение степени дифференциации развития муниципальных образований в } \\
\text { экономической и социальной сферах }\end{array}$ \\
\hline & $\begin{array}{l}\text { 3. Повышение } \\
\text { качества жизни } \\
\text { населения }\end{array}$ & $\begin{array}{l}\text { 3.1. Рост капитализации человеческих ресурсов. } \\
\text { 3.2. Достижение баланса на рынке труда, включая подчинение системы профобра- } \\
\text { зования рыночным потребностям. } \\
\text { 3.3. Повышение инфраструктрной обеспеченности в социальной сфере и обеспече- } \\
\text { ние роста уровня потребления. } \\
\text { 3.4. Улучшение демографической ситуации. } \\
\text { 3.5. Повышение уровня экологической безопасности } \\
\end{array}$ \\
\hline
\end{tabular}


Продолжение таблиць 1

\begin{tabular}{|c|c|c|}
\hline Регион & $\begin{array}{c}\text { Стратегические } \\
\text { цели } \\
\end{array}$ & Задачи \\
\hline \multirow[t]{3}{*}{$\begin{array}{l}\text { Респуб- } \\
\text { лика } \\
\text { Калмы- } \\
\text { кия }\end{array}$} & $\begin{array}{l}1 . \text { Достижение } \\
\text { материального } \\
\text { благосостояния } \\
\text { и качества жиз- } \\
\text { ни населения }\end{array}$ & $\begin{array}{l}\text { 1.1. Повышение комфортности проживания населения. } \\
\text { 1.2. Развитие системы водоснабжения. } \\
\text { 1.3. Рост доходов населения: } \\
\text { - увеличение заработной платы; } \\
\text { - легализация выплат; } \\
\text { - ликвидация задолженностей. } \\
\text { 1.4. Улучшение демографической ситуации }\end{array}$ \\
\hline & $\begin{array}{l}2 . \text { Сбалансиро- } \\
\text { ванное и устой- } \\
\text { чивое развитие } \\
\text { экономики рес- } \\
\text { публики }\end{array}$ & $\begin{array}{l}\text { 2.1. Повышение эффективности территориального размещения производственных } \\
\text { сил, проведение экономического районирования. } \\
\text { 2.2. Формирование положительного имиджа для привлечения инвестиций. } \\
\text { 2.3. Создание инновационной системы республики. } \\
\text { 2.4. Формирование промышленно-производственной зоны опережающего развития. } \\
\text { 2.5. Развитие ключевых секторов экономики на основании кластерного подхода: аг- } \\
\text { ропромышленного комплекса, биотех нологического и нефтехимического. } \\
\text { 2.6. Стимулирование и развитие малого бизнеса. } \\
\text { 2.7. Расширение транспортной инфраструктуры. } \\
\text { 2.8. Развитие туристкой деятельности. } \\
\text { 2.9. Развитие межрегионального сотрудничества и внешнеэкономической деятельности }\end{array}$ \\
\hline & $\begin{array}{l}\text { 3. Создание бла- } \\
\text { гоприятных усло- } \\
\text { вий жизнедея- } \\
\text { тельности насе- } \\
\text { ления }\end{array}$ & $\begin{array}{l}\text { 3.1. Развитие социальной инфраструктуры. } \\
\text { 3.2. Повышение доступности и качества услуг здравоохранения и образования. } \\
\text { 3.3. Формирование условий для развития профессионального массового спорта. } \\
\text { 3.4. Развитие и сохранение культурного потенциала }\end{array}$ \\
\hline \multirow[t]{7}{*}{$\begin{array}{l}\text { Волго- } \\
\text { градская } \\
\text { область }\end{array}$} & $\begin{array}{l}\text { 1. Повышение } \\
\text { уровня жизни } \\
\text { населения }\end{array}$ & $\begin{array}{l}\text { 1.1. Увеличение доходов населения, в том числе: } \\
\text { - снижение уровня безработицы; } \\
\text { - сокращение размера задолженностей по заработной плате. } \\
\text { 1.2. Сдерживание роста цен }\end{array}$ \\
\hline & $\begin{array}{l}\text { 2. Развитие эко- } \\
\text { номики }\end{array}$ & $\begin{array}{l}\text { 2.1. Повышение инвестиционной привлекательности региона. } \\
\text { 2.2. Развитие торговли и предпринимательской деятельности. } \\
\text { 2.3. Развитие агропромышленного комплекса. } \\
\text { 2.4. Развитие обрабатывающих производств. } \\
\text { 2.5. Развитие финансовой инфраструктуры. } \\
\text { 2.6. Повышение инновационного и научно-технического развития. } \\
\text { 2.7. Развитие межрегиональных и международных отношений и сотрудничества }\end{array}$ \\
\hline & $\begin{array}{l}\text { 3. Развитие со- } \\
\text { циальной сферы }\end{array}$ & $\begin{array}{l}\text { 3.1. Повышение уровня здоровья населения. } \\
\text { 3.2. Повышение качества и доступности образования. } \\
\text { 3.3. Повышение уровня социальной защиты населения. } \\
\text { 3.4. Повышение эффективности содействия занятости. } \\
\text { 3.5. Формирование условий для досуга, духовного развития населения, а также за- } \\
\text { нятий спортом и физической культурой. } \\
\text { 3.6. Улучшение условий для развития молодежи }\end{array}$ \\
\hline & $\begin{array}{l}\text { 4. Развитие ин- } \\
\text { фраструктуры }\end{array}$ & $\begin{array}{l}\text { 4.1. Улучшение условий проживания. } \\
\text { 4.2. Сдерживание роста тарифов в сфере ЖКХ, транспорта. } \\
\text { 4.3. Сдерживание роста инфраструктурных издержек, рисков и ограничений для } \\
\text { развития и осуществления бизнеса. } \\
\text { 4.4. Повышение энергоэффективности региона. } \\
\text { 4.5. Повышение обеспеченности экономики природными ресурсами, а также эколо- } \\
\text { гической безопасности и устойчивости. } \\
\text { 4.6. Создание эффективной системы территориального планирования и развития }\end{array}$ \\
\hline & $\begin{array}{l}\text { 5. Повышение } \\
\text { безопасности }\end{array}$ & $\begin{array}{l}\text { 5.1. Сокращение уровня преступности. } \\
\text { 5.2. Повышение степени защищенности населения от техногенных и природный } \\
\text { аварий, безопасности дорожного движения. } \\
\text { 5.3. Ужесточение требований к производственной технике безопасности. } \\
\text { 5.4. Совершенствование действующей системы по защите прав потребителей }\end{array}$ \\
\hline & $\begin{array}{l}\text { 6. Управление } \\
\text { общественными } \\
\text { финансами }\end{array}$ & $\begin{array}{l}\text { 6.1. Увеличение поступлений в бюджет. } \\
\text { 6.2. Увеличение финансирования из федерального бюджета и эффективности их } \\
\text { расходования. } \\
\text { 6.3. Оптимизация управления государственным долгом }\end{array}$ \\
\hline & $\begin{array}{l}\text { 7. Развитие об- } \\
\text { щего государст- } \\
\text { венного управ- } \\
\text { ления }\end{array}$ & $\begin{array}{l}\text { 7.1. Развитие системы регионального стратегирования, повышение уровня досто- } \\
\text { верности прогнозов. } \\
\text { 7.2. Повышение качества и организации предоставления государственных услуг, } \\
\text { развитие применения информационных технологий }\end{array}$ \\
\hline
\end{tabular}


Окончание таблицьы 1

\begin{tabular}{|c|c|c|}
\hline Регион & $\begin{array}{c}\text { Стратегические } \\
\text { цели }\end{array}$ & Задачи \\
\hline \multirow[t]{3}{*}{$\begin{array}{l}\text { Ставро- } \\
\text { польский } \\
\text { край }\end{array}$} & $\begin{array}{l}\text { 1. Повышение } \\
\text { уровня социаль- } \\
\text { ного развития }\end{array}$ & $\begin{array}{l}\text { 1.1. Создание условий для всесторонней реализации личности и поддержки соци- } \\
\text { ально уязвимых групп населения, гармонизация межнациональных отношений. } \\
\text { 1.2. Создание комфортной среды для проживания в регионе, обеспечение комфорт- } \\
\text { ным жильем. } \\
\text { 1.3. Повышение доступности и качества социальных услуг населению. } \\
\text { 1.4. Преодоление бедности, повышение социальной ответственности и производи- } \\
\text { тельности труда бизнеса. } \\
\text { 1.5. Улучшение демографической ситуации. } \\
\text { 1.6. Повышение уровня экологической безопасности }\end{array}$ \\
\hline & $\begin{array}{l}\text { 2. Развитие эко- } \\
\text { номики }\end{array}$ & $\begin{array}{l}\text { 2.1. Повышение эффективности использования ресурсного потенциала региона для } \\
\text { повышения конкурентоспособности экономики. } \\
\text { 2.2. Преодоление неравномерности территориального развития. } \\
\text { 2.3. Создание условий для перехода к инновационному типу развития экономики. } \\
\text { 2.4. Рост инвестиционной привлекательности. } \\
\text { 2.5. Усиление позиций в промышленной и аграрной сферах страны, в целом. } \\
\text { 2.6. Создание ведущего в стране туристско-рекреационного и лечебно- } \\
\text { оздоровительного комплекса. } \\
\text { 2.7. Развитие малого предпринимательства. } \\
\text { 2.8. Развитие региональной оптовой сети, терминалов. } \\
\text { 2.9. Экологизация хозяйственной деятельности }\end{array}$ \\
\hline & $\begin{array}{l}3 . \\
\text { Фиермирова- } \\
\text { тивного аппулара- } \\
\text { та регионально- } \\
\text { го управления }\end{array}$ & $\begin{array}{l}\text { 3.1. Формирование нового организационно-управленческого механизма. } \\
\text { 3.2. Укрепление существующих и создание новых региональных институтов разви- } \\
\text { тия, институтов гражданского общества. } \\
\text { 3.3. Развитие механизма ГЧП }\end{array}$ \\
\hline \multirow[t]{4}{*}{$\begin{array}{l}\text { Красно- } \\
\text { дарский } \\
\text { край }\end{array}$} & $\begin{array}{l}\text { 1. Повышение } \\
\text { продолжитель- } \\
\text { ности и качества } \\
\text { жизни }\end{array}$ & $\begin{array}{l}\text { 1.1. Рост доходов населения. } \\
\text { 1.2. Повышение сроков продолжительности жизни. } \\
\text { 1.3. Развитие образования и здравоохранения. } \\
\text { 1.4. Доступность жилья }\end{array}$ \\
\hline & $\begin{array}{l}\text { 2. Обеспечение } \\
\text { высоких темпов } \\
\text { роста экономики }\end{array}$ & $\begin{array}{l}\text { 2.1. Формирование условий для устойчивого развития. } \\
\text { 2.2. Обеспечение значительных темпов устойчивого роста отраслей экономики ре- } \\
\text { ального сектора }\end{array}$ \\
\hline & $\begin{array}{l}\text { 3. Создание по- } \\
\text { тенциала опере- } \\
\text { жающего разви- } \\
\text { тия края для вы- } \\
\text { полнения функ- } \\
\text { ции опорного } \\
\text { региона }\end{array}$ & $\begin{array}{l}\text { 3.1. Увеличение доли региона в приросте ВВП страны. } \\
\text { 3.2. Наращивание потенциала в региональном образовании и науке, а также в соци- } \\
\text { ально-экономической сфере. } \\
\text { 3.3. Стимулирование стратегического взаимодействия бизнеса. власти, а также гра- } \\
\text { жданского общества. } \\
\text { 3.4. Повышение объемов пассажиро- и грузопотока }\end{array}$ \\
\hline & $\begin{array}{l}4 . \quad \text { Повышение } \\
\text { эффективности } \\
\text { государственного } \\
\text { стратегического } \\
\text { планирования и } \\
\text { регулирования } \\
\text { социально-эконо- } \\
\text { мических про- } \\
\text { цессов }\end{array}$ & $\begin{array}{l}\text { 4.1. Формирование и совершенствование систем стратегического управления, опти- } \\
\text { мизации институциональной структуры, пространственного развития и территори- } \\
\text { ального планирования. } \\
\text { 4.2. Реализация административной реформы. } \\
\text { 4.3. Повышение эффективности управления бюджетными учреждениями и государ- } \\
\text { ственным имуществом. } \\
\text { 4.4. Совершенствование межбюджетных отношений и внедрение новых механизмов } \\
\text { взаимдействия с органами самоуправления на местах. } \\
\text { 4.5. Развитие муниципальной статистики }\end{array}$ \\
\hline
\end{tabular}

Примечание. Составлено по: [6; 7; 10-12].

ленности, инфраструктуры, туристско-рекреационных комплексов; совершенствование системы регионального и бюджетного управления.

В качестве ресурсного обеспечения данных стратегий приводятся исключительно финансовые средства с указанием объемов денежных средств, предоставляемых из раз- личных источников. При этом вопросы обеспеченности природными ресурсами, такими как вода, почва и др., не рассматриваются.

Иными словами, реальной практикой регионального стратегирования фиксируется тот факт, что планирование развития регионов страны на долгосрочную перспективу происходит без 
оценки требуемого количества природных ресурсов и их качественных характеристик. Однако каждая из стратегий подразумевает наращивание объемов производства в различных сферах экономической деятельности, которые априори повлекут за собой увеличение объемов потребления природных ресурсов.

Наиболее остро для исследуемых регионов, да и для мира в целом, стоит проблема дефицита водных ресурсов, особенно пресной воды. Данное обстоятельство определяется тем, что мировые объемы потребления водных ресурсов постоянно увеличиваются, причем их использование имеет экстенсивный характер, имеющий следствием сокращение экономически доступных водных ресурсов ввиду нарушения механизма их естественного воспроизводства. Уже сейчас можно говорить о том, что дефицит пресной воды выступает сдерживающим фактором экономического роста большого числа стран. Нехватка водных ресурсов при- водит к социальной, экономической и, как следствие, политической нестабильности.

В анализируемых регионах также наблюдается недообеспеченность водными ресурсами. Так, например, администрацией Ростовской области уже на протяжении 6 лет фиксируется, что в области наблюдается дефицит водных ресурсов [1]. Республика Калмыкия является маловодным регионом с дефицитом поверхностных водных источников, а в Ставропольском крае отмечены ограниченные запасы водных ресурсов при высокой потребности в них. В связи с этим анализ уровня и качества водообеспеченности региональных стратегий является особенно актуальным.

В ходе исследования были выявлены основные задачи регионального стратегирования исследуемых территорий, требующие повышения использования или нагрузки на водные ресурсы и объекты. Их результаты представлены в таблице 2.

Таблица 2

\section{Задачи стратегий регионального развития, требующие повышения использования} или нагрузки на водные ресурсы и объекты

\begin{tabular}{|c|c|c|}
\hline Регион & Стратегические цели и задачи & $\begin{array}{c}\text { Способ использования } \\
\text { водных объектов }\end{array}$ \\
\hline \multirow[t]{6}{*}{$\begin{array}{l}\text { Ростов- } \\
\text { ская об- } \\
\text { ласть }\end{array}$} & $\begin{array}{l}\text { 1. Агропромышленный комплекс: } \\
\text { - увеличение объемов производства продукции АПК; } \\
\text { - увеличение доли перерабатывающей промышленности; } \\
\text { - воспроизводство и сохранение с/х почв }\end{array}$ & $\begin{array}{l}\text { С изъятием без возврата } \\
\text { С изъятием и возвратом }\end{array}$ \\
\hline & $\begin{array}{l}\text { 2. Создание новых производств и модернизация действующих, увеличение } \\
\text { объемов производства в машиностроительном, металлургическом ком- } \\
\text { плексе, химическом производстве, легкой промышленности, добыче и пе- } \\
\text { реработке полезных ископаемых }\end{array}$ & $\begin{array}{l}\text { С изъятием без возврата } \\
\text { С изъятием и возвратом }\end{array}$ \\
\hline & $\begin{array}{l}\text { 3. Строительство: } \\
\text { - увеличение объемов строительства жилья; } \\
\text { - увеличение объемов строительства, технического перевооружения и ре- } \\
\text { конструкции предприятий, сооружений и зданий в сфере производствен- } \\
\text { ного строительства }\end{array}$ & С изъятием и возвратом \\
\hline & $\begin{array}{l}\text { 4. Развитие воднотранспортного комплекса: } \\
\text { - увеличение грузопотоков через порты; } \\
\text { - восстановление судоходных путей на реках Маныч и Северский Донец; } \\
\text { - восстановления пассажирского судоходства; } \\
\text { - развитие экскурсионно-прогулочного обслуживания }\end{array}$ & Без изъятия \\
\hline & $\begin{array}{l}\text { 5. Развитие терминально-логистической и транспортно-складской инфра- } \\
\text { структуры, реализация транзитного потенциала }\end{array}$ & Без изъятия \\
\hline & $\begin{array}{l}\text { 6. Развитие энергетической инфраструктуры, увеличение объемов произ- } \\
\text { водства электроэнергии }\end{array}$ & Все виды \\
\hline $\begin{array}{l}\text { Респуб- } \\
\text { лика } \\
\text { Калмы- } \\
\text { кия }\end{array}$ & $\begin{array}{l}\text { 1. Агропромышленный комплекс: } \\
\text { - увеличение объемов производства с/х продукции, в том числе плодо- } \\
\text { овощеводства, овцеводства и молочного животноводства; } \\
\text { - восстановление плодородия земель; } \\
\text { - создание новых предприятий прудового рыбоводства и хозяйств, строи- } \\
\text { тельство осетрового рыбного комплекса; } \\
\text { - модернизация и техническое перевооружение действующих и строи- } \\
\text { тельство новых рыбоперерабатывающих комплексов }\end{array}$ & Все виды \\
\hline
\end{tabular}


Окончание таблищь 2

\begin{tabular}{|c|c|c|}
\hline Регион & Стратегические цели и задачи & $\begin{array}{l}\text { Способ использования } \\
\text { водных объектов }\end{array}$ \\
\hline \multirow[t]{3}{*}{$\begin{array}{l}\text { Респуб- } \\
\text { лика } \\
\text { Калмы- } \\
\text { кия }\end{array}$} & $\begin{array}{l}\text { 2. Добыча и обработка полезных ископаемых и сырья: } \\
\text { - разведка и увеличение добычи углеводородного сырья; } \\
\text { - организация производства биотоплива; } \\
\text { - рационализация системы лицензирования прав на добычу и переработку } \\
\text { сырья, изготовление строительных материалов; } \\
\text { - создание и наращивание новых мощностей по производству вяжущих } \\
\text { материалов, различных панелей, стекловолоконных изделий, различных } \\
\text { видов строительных щебня, песка и гравия } \\
\text { 3. Увеличение объемов производства, передачи и распределения электро- } \\
\text { энергии и воды }\end{array}$ & $\begin{array}{l}\text { С изъятием без возврата } \\
\text { С изьятием и возвратом }\end{array}$ \\
\hline & $\begin{array}{l}\text { 4. Строительство Манычского судоходного канала (между Каспийским и } \\
\text { Азовским морями) }\end{array}$ & Без изъятия \\
\hline & $\begin{array}{l}\text { 5. Туристско-рекреационный комплекс: } \\
\text { - реконструкция действующих и построение новых объектов; } \\
\text { - развитие оздоровительного комплекса с бальнеотерапевтическим лече- } \\
\text { нием на берегу оз. Большое Яшалтинское }\end{array}$ & Все виды \\
\hline \multirow[t]{2}{*}{$\begin{array}{l}\text { Волго- } \\
\text { градская } \\
\text { область }\end{array}$} & $\begin{array}{l}\text { 1. Агропромышленный комплекс: } \\
\text { - развитие и модернизация гидромелиоративного комплекса; } \\
\text { - строительство и модернизация предприятий по переработке плодовых и } \\
\text { овощных культур, маслоэкстракционного производства; } \\
\text { - рост объемов производства в мясном птицеводстве, молочном и мясном } \\
\text { скотоводстве; } \\
\text { - увеличение объемов в } 5 \text { раз к } 2020 \text { г. производства продуктов питания и } \\
\text { продовольственных товаров; } \\
\text { - повышение обеспеченности сельского населения питьевой водой }\end{array}$ & $\begin{array}{l}\text { С изъятием без возврата } \\
\text { С изъятием и возвратом }\end{array}$ \\
\hline & $\begin{array}{l}\text { 2. Промышленность: планируется увеличение объемов производства: } \\
\text { - в пищевой промышленности - в } 5 \text { раз; } \\
\text { - в металлургии отрасли - в 1,3 раза; } \\
\text { - в химической отрасли - в } 3,5 \text { раза; } \\
\text { - в добывающей отрасли - в 1,2 раза }\end{array}$ & $\begin{array}{l}\text { С изъятием без возврата } \\
\text { С изъятием и возвратом }\end{array}$ \\
\hline \multirow[t]{4}{*}{$\begin{array}{l}\text { Ставро- } \\
\text { польский } \\
\text { край }\end{array}$} & $\begin{array}{l}\text { 1. Развитие агропромышленного комплекса, повышение плодородия почв, } \\
\text { увеличение объемов производства основных видов с/х продукции и про- } \\
\text { довольствия }\end{array}$ & $\begin{array}{l}\text { С изъятием без возврата } \\
\text { С изъятием и возвратом }\end{array}$ \\
\hline & $\begin{array}{l}\text { 2. Промышленность: } \\
\text { - строительство и модернизация производственных мощностей, увеличе- } \\
\text { ние объемов производства в приборостроении, электроэнергетике, сте- } \\
\text { кольной, химической, нефтехимической и парфюмерно-косметической } \\
\text { отрасли, легкой и пищевой промышленности }\end{array}$ & $\begin{array}{l}\text { С изъятием без возврата } \\
\text { С изъятием и возвратом }\end{array}$ \\
\hline & $\begin{array}{l}\text { 3. Развитие топливно-энергетического комплекса: строительство гидро- } \\
\text { электростанций, использование геотермальных вод как альтернативных } \\
\text { источников энергии }\end{array}$ & $\begin{array}{l}\text { С изъятием без возврата } \\
\text { С изъятием и возвратом }\end{array}$ \\
\hline & $\begin{array}{l}\text { 4. Развитие туристско-рекреационного комплекса Кавказских Минераль- } \\
\text { ных Вод }\end{array}$ & Все виды \\
\hline \multirow[t]{4}{*}{$\begin{array}{l}\text { Красно- } \\
\text { дарский } \\
\text { край }\end{array}$} & $\begin{array}{l}\text { 1. Увеличение объемов жилищного строительства и модернизация объек- } \\
\text { тов коммунальной инфраструктуры, в том числе жилищно-коммунального } \\
\text { комплекса }\end{array}$ & $\begin{array}{l}\text { С изъятием без возврата } \\
\text { С изъятием и возвратом }\end{array}$ \\
\hline & $\begin{array}{l}\text { 2. Агропромышленный комплекс: } \\
\text { - восстановление и развитие виноградников и садов; } \\
\text { - увеличение объемов выпуска импортозамещающей и экспортной про- } \\
\text { дукции; } \\
\text { - ускоренное развитие животноводства, увеличение объемов производства }\end{array}$ & $\begin{array}{l}\text { С изъятием без возврата } \\
\text { С изъятием и возвратом }\end{array}$ \\
\hline & $\begin{array}{l}\text { 3. Развитие инфраструктуры морских портов: } \\
\text { - строительство нового грузового порта «Тамань»; } \\
\text { - пополнение флота судоходных компаний; } \\
\text { - восстановление морского пассажирского сообщения между прибрежны- } \\
\text { ми городами на Азовском и Черном морях; } \\
\text { - расширение географии международных пассажирских перевозок }\end{array}$ & Без изъятия \\
\hline & $\begin{array}{l}\text { 4. Развитие туристической отрасли: } \\
\text { - увеличение численности туристов; } \\
\text { - развитие использования гидроминеральной базы }\end{array}$ & Все виды \\
\hline
\end{tabular}

Примечание. Составлено по: [6; 7; 10-12]. 
Как видно из данных таблицы 2, рассмотренные стратегии регионального развития исследуемых регионов предполагают значительное увеличение объемов потребления водных ресурсов. В агропромышленном комплексе вода в основном используется для нужд мелиорации и орошения. При этом большая часть воды изымается безвозвратно, тем самым повышая водоемкость данного вида деятельности. Увеличение объемов производства промышленной продукции также повышает водопотребление, поскольку вода является непосредственным участником производственного процесса практически всех отраслей промышленности. Данная ситуация усугубляется еще и тем, что специализация исследуемых регионов характеризуется самыми водоемкими отраслями промышленности, к которым относятся теплоэнергетика, черная и цветная металлургия, машиностроение, нефтехимическая промышленность.

Отдельно следует отметить самую водоемкую отрасль - электроэнергетику. Увеличение объемов производимой энергии, развитие мощностей и строительство новых гидроэлектростанций заявлено во всех стратегиях регионального развития, что обусловлено потребностями социально-экономического развития данных территорий.

Развитие и увеличение темпов жилищного строительства приводит к увеличению объемов потребления воды на хозяйственнобытовые нужды в связи с улучшением уровня жизни граждан. К тому же развитие данной отрасли приводит к расширению коммунальных сетей, систем водоснабжения и водоотведения.

Развитие транспортно-логистической сети приводит к повышению нагрузки на поверхностные водные объекты в силу использования их в качестве судоходных путей для грузовых и пассажирских кораблей. При этом увеличивается загрязнение рек нефтяными, горючесмазочными веществами, бытовым мусором.

Увеличение туристической нагрузки и развитие туристско-рекреационных комплексов приводит к повышению использования водных ресурсов, реализуя все виды водопользования. Наличие запасов минеральных вод высокого качества с признанными лечебны- ми свойствами в Ставропольском, Краснодарском крае и Республике Калмыкия приводит к возрастающему спросу на данные виды ресурсов со стороны населения всей территории России и ближнего зарубежья. При этом минеральные воды используются в двух направлениях: потребляются населением и используются в качестве мест для купания и принятия минеральных ванн. Что касается поверхностных водных объектов, то основная рекреационная нагрузка приходится на побережья Черного и Азовского морей. Водные объекты используются для купания, в качестве судоходных путей в части организации прогулок и экскурсий на водных видах транспорта. К тому же приток туристов приводит к увеличению объемов потребления воды на хозяйственно-бытовые нужды, водоснабжение и водоотведение.

Проблемы водообеспеченности тесно связаны и с качественным состояние водных объектов анализируемых регионов. Данная ситуация обусловлена тем, что забор воды в необходимом объеме, но ненадлежащего качества для производственных, сельскохозяйственных, коммунальных или бытовых нужд приводит к необходимости ее доочистки и приведения к требуемым нормативным показателям качества. Это, в свою очередь, приводит к удорожанию и увеличению длительности производственного цикла и негативно сказывается на уровне жизни населения, на деятельности предприятий и организаций, отраслей, регионов и страны в целом.

Мониторинг экологического состояния водных объектов позволил получить следующие результаты.

1. Все водные объекты Ростовской области, включая как поверхностные, так и подземные источники, подвержены техногенному и антропогенному воздействию. Степень и интенсивность воздействия колеблется в зависимости от территориального расположения. В настоящее время в области наблюдается усиление заиления русел рек, особенно малых. Также характерной проблемой для описываемого региона является зарастание водных объектов кустарниковой и древесной растительностью, заболачивание. Не менее важной проблемой выступает повышение объемов застраивания водоемов инженерны- 


\section{ЭкоЛОГИя}

ми сооружениями. Последствиями данных негативных тенденций является деградация водных ресурсов, приводящая к невозможности использования их в хозяйственно-бытовой деятельности, как источник водоснабжения, для нужд рыболовства и рыбоводства.

Всего за 2016 г. было сброшено сточных вод 1 422,66 млн куб. м. Данный показатель выше уровня предыдущего года на 3,4 \%, что свидетельствует о преобладании негативных тенденций. Важно отметить, что почти $35 \%$ сброшенной воды было загрязнено или недостаточно очищено. На рисунке представлены отрасли, являющиеся основными загрязнителями поверхностных водных объектов на территории Ростовской области.

Как видно из диаграммы, представленной на рисунке, основными загрязнителями водных объектов Ростовской области на протяжении длительного времени являются предприятия жилищно-коммунального хозяйства. Загрязняющими веществами водных ресурсов региона являются: нефтепродукты, азот, органические вещества, соединения меди, нитраты, нитриты, фенолы, железо, сульфаты, магний, ядохимикаты, пестициды, цинк. При этом предельно допустимые концентрации вредных веществ превышены в несколько раз. В целом, состояние воды в водных объектах, расположенных на территории Ростовской области, колеблется от «умеренно-загрязненной» до «очень грязной» [9].

2. Республика Калмыкия характеризуется крупными экологическими проблемами, особенно в части загрязнения водных объектов, как поверхностных, так и подземных. Одним из негативных факторов загрязнения водных объектов является территориальное расположение региона. Основными источниками загрязнений выступают прилегающие к Калмыкии предприятия Астраханской, Волгоградской областей и Ставропольского края, к которым относятся сельскохозяйственные комплексы, химическое, металлургическое и топливно-энергетическое производство. По обобщенным данным, ежегодно эти предприятия сбрасывают примерно 3 млн куб. м загрязненных сточных вод, содержа-

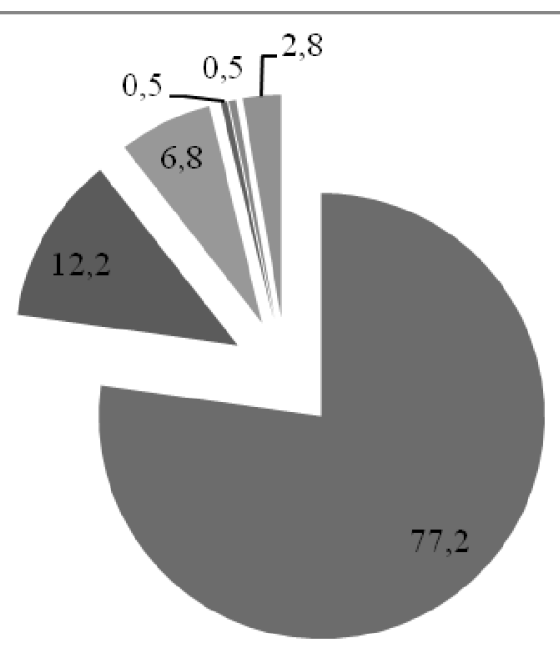

77,2 \% (1 099 млн куб. м) - производство, передача и распределение электроэнергии, пара и горячей воды

$12,2 \%$ (173,97 млн куб. м) - сельское хозяйство, охота, лесное хозяйство

$6,8 \%$ (97,47 млн куб. м) - рыболовство, рыбоводство

$0,5 \%$ (7,85 млн куб. м) - добыча полезных ископаемых

$0,5 \%$ (7,75 млн куб. м) - обрабатывающие производства

2,8 \% (36,35 млн куб. м) - прочие нужды

Рисунок. Объемы потребления водных ресурсов в Ростовской области по отраслям за 2016 год Примечание. Составлено по: [9]. 
щих не менее 200 видов веществ различной степени опасности. Данная ситуация усугубляется наличием большого количества месторождений подземных вод на территории региона, которые аккумулируют вредные вещества и распространяют по всей территории. В целом 86,3\% всех загрязненных сточных вод сброшено из приграничных территорий Калмыкии.

Оценка качества проб воды показывает неудовлетворительные результаты: $80,5 \%$ проб не отвечают нормативным требованиям по санитарно-химическим показателям и более $30 \%$ - по микробиологическим.

К основным загрязняющим веществам водных источников Калмыкии относятся: сульфаты, фенолы, хлориды, бикарбонаты, кальций, железо, пестициды, азотосодержащие соединения, тригалометаны, фтор.

Основными источниками техногенной нагрузки на водные объекты данного региона выступают перерабатывающая промышленность и агропромышленный комплекс, а также добыча подземных вод и углеводородного сырья и последующая их переработка. К основным источникам загрязнения относятся коллекторно-дренажные воды и канализационные стоки. Всего за 2016 г. в водные объекты республики было сброшено 18,87 млн куб. м, из которых без очистки - 14,91 млн куб. м. Ежегодные потери воды при транспортировке составляют в среднем 280 млн куб. м [5].

3. На качество реки Дон и вод ее бассейна значительное влияние оказывают сельскохозяйственные и промышленные стоки предприятий, располагающихся в Волгоградской, Воронежской, Липецкой, Курской и Тамбовской областях. К основным загрязняющим веществам относятся: железо, азот аммонийный, сульфаты, фосфаты, хлориды, марганец.

Следует отметить, что по территории области протекает еще одна крупная река Волга. Однако данная ситуация не делает возможным высокое качество обеспеченности области водными ресурсами в связи с сильной степенью ее загрязнения. По проведенному мониторингу степени загрязненности река относится к разряду $3 \mathrm{~A}$ - «загрязненная», также имеется участок, вода которого относятся к разряду ЗБ - «очень загрязненная» [2].
4. Поверхностные водные объекты Ставропольского края относятся к следующим бассейновым округам: Кубанскому (река Кубань), Донскому (реки Калаус и Егорлык) и Западно-Каспийскому (река Кума). Несмотря на это, располагаемые водные ресурсы не обеспечивают водопотребление в требуемом объеме, в регионе наблюдается их дефицит.

Состояние водных ресурсов Ставропольского края можно в целом оценить как неудовлетворительное. По проведенному мониторингу степени загрязненности получены следующие результаты:

- водные объекты бассейна реки Кумы относятся к разряду 4А - «грязная»;

- озеро Буйвола, вода относится к разряду 4В - «очень грязная»;

- водные объекты бассейна реки Калаус колеблются от разряда 4A - «грязная» до разряда 5 - «экстремально грязная»;

- водные объекты бассейна реки Егорлык колеблются от разряда 2 - «слабозагрязненная» до разряда 4A - «грязная».

Основными загрязняющими веществами выступают нитриты, марганец, сульфаты, магний, фосфаты, медь, цинк, нефтепродукты, свинец [3].

5. Поверхностные водные объекты Краснодарского края относятся к следующим бассейновым округам: реки бассейна Азовского моря междуречья Дона и Кубани, реки бассейна Черного моря и бассейн реки Кубань. Следует отметить, что расположение водных ресурсов по территории края является неравномерным, наименее обводненной выступает степная зона.

Загрязнение водных объектов края также происходит неравномерно. Ключевыми источниками засорения рек выступают неорганизованные ливневые и хозяйственно-бытовые стоки, коммунальные хозяйства, строительные и санаторно-курортные отрасли. Реки степной зоны Краснодарского края подвержены загрязнению и засорению за счет сброса сточных вод и выноса в реки загрязняющих примесей в составе поверхностных сточных вод с прилегающих к водным объектам территорий.

Основными веществами, загрязняющими водные объекты края, выступают: гидрокарбонаты, фосфаты, сульфаты, магний, фе- 
нолы, кальций, цинк, медь, свинец, ртуть, формальдегиды.

По проведенному мониторингу степени загрязненности получены следующие результаты: воды Краснодарского водохранилища относятся к разряду ЗБ - «очень загрязненная»; бассейны рек Кубани и Восточного Приазовья колеблются от разряда 2 - «слабо загрязненная» до разряда 4А - «грязная»; реки северо-восточного побережья Черного моря относятся к разряду $3 \mathrm{~A}$ - «загрязненная»; для контролируемой акватории коэффициент комплексности загрязнения морских вод составил $38 \%$, что указывает на влияние антропогенного фактора на качество морских вод. В 2016 г. морские воды в акватории порта Сочи по качеству отнесены к III классу и охарактеризованы как «умеренно загрязненные», остальная акватория - к разряду 2 - «слабозагрязненная».

Годовой объем сбрасываемых сточных вод составляет 2976 млн куб. м, при этом $28,82 \%$ из них (то есть практически $1 / 3$ всей сточной воды) являются загрязненными или недостаточно очищенными. Общие потери воды при транспортировке в Краснодарском крае - 966,18 млн куб. м, или 16,26 \% забранной воды. Регион занимает первое место в России по данному показателю [4].

Таким образом, можно сделать вывод, что обеспеченность стратегий социально-экономического развития исследуемых регионов водой является крайне низкой. Большинство стратегических целей подразумевает значительное повышение объемов использования и эксплуатации водных ресурсов при уже имеющемся их дефиците. Из всех анализируемых регионов только Краснодарский край не имеет явного дефицита водных ресурсов в масштабах всего региона. Усугубляет ситуацию неудовлетворительное состояние имеющихся водных объектов, которое приводит к еще большему сокращению объемов воды, пригодной для хозяйственно-бытовых, сельскохозяйственных и промышленных нужд. Мониторинг качества водных объектов регионов бассейна Нижнего Дона позволил выявить, что качество поверхностных водных объектов оценивается как неудовлетворительное. Качество поверхностных региональных объектов колеблется от класса $3 \mathrm{~A}$ «загрязненная» до класса 5 - «экстремально грязная», исключением являются некоторые участки бассейнов рек Кубани и Восточного Приазовья, класс загрязнения которых оценивается как 2 - «слабо загрязненная». В соответствии с этим планируемые темпы социальноэкономического развития исследуемых регионов могут сдерживаться качественным и количественным состоянием располагаемых водных ресурсов, выступая препятствием для наращивания производственного потенциала и повышения качества жизни населения.

\section{ПРИМЕЧАНИЕ}

${ }^{1}$ Статья подготовлена в рамках гранта РФФИ 18-010-00623 «Интеллектуальное моделирование организационно-экономического механизма управления водоресурсным обеспечением региональных водохозяйственных комплексов».

\section{СПИСОК ЛИТЕРАТУРЫ}

1. В Ростовской области наблюдается дефицит водных ресурсов // Новости министерства природных ресурсов и экологии Ростовской области. Электрон. текстовые дан. - Режим доступа: http:// xn-d1ahaoghbejbc5k.xn-p1ai/news/v-rostovskoyoblasti-nablyudaetsya-defitsit-vodnykh-resursov/ (дата обращения: 30.05.2018).

2. Доклад «О состоянии окружающей среды Волгоградской области в 2016 году». - Ижевск : Принт-2, 2017. - Электрон. текстовые дан. - Режим доступа: http://www.ecoindustry.ru/gosdoklad/ view/419.html\# (дата обращения: 02.06.2018). - Загл. с экрана.

3. Доклад о состоянии окружающей среды и природопользовании в Ставропольском крае в 2016 году. - Ставрополь, 2017. - Электрон. текстовые дан. - Режим доступа: http://www.mpr26.ru/deyatelnost/ otchety-doklady/o-sostoyanii-okruzhayushchey-sredy-iprirodopolzovanii-v-stavropolskom-krae/ (дата обращения: 02.06.2018). - Загл. с экрана.

4. Доклад о состоянии природопользования и об охране окружающей среды Краснодарского края в 2016 году. - Краснодар, 2017. - Электрон. текстовые дан. - Режим доступа: http://www.mprkk.ru/obokruzhayuschej-srede/o-sostoyanii-okruzhayuschejsredyi/ezh egodnyij-doklad-o-sostoyaniiprirodopolzovaniya-i-ohrane-okruzhayuschej-sredyikrasnodarskogo-kraya/ (дата обращения: 02.06.2018). Загл. с экрана.

5. Доклад об экологической ситуации на территории Республики Калмыкия в 2016 году. - Элиста, 2017. - Электрон. текстовые дан. - Режим доступа: 
http://www.ecoindustry.ru/gosdoklad/view/430.html (дата обращения: 02.06.2018). - Загл. с экрана.

6. Закон Волгоградской области «О стратегии социально-экономического развития Волгоградской области до 2020 года» № 1778-ОД от 21.11.2008 г. : принят Волгоградской областной Думой 30.10.2008 г. - Электрон. текстовые дан. - Режим доступа: http:/volgoduma.ru/images/stories/files/ strategija_2020.pdf(дата обращения: 28.05.2018).Загл. с экрана.

7. Закон Краснодарского края «О Стратегии социально-экономического развития Краснодарского края до 2020 года» № 1465-КЗ от 29.04.2008 г. : принят Законодательным Собранием Краснодарского края 16.04.2008 г. - Электрон. текстовые дан. - Режим доступа: http://www.krasnodar.ru/content/38/show/ 49460/\# (дата обращения: 28.05.2018). - Загл. с экрана.

8. Матвеева, Л. Г. Государственная компонента инновационного потенциала региональной промышленности / Л. Г. Матвеева // Государственное и муниципальное управление (Ученые записки СКАГС). - 2012. - № 2. - С. 32-38.

9. О состоянии окружающей среды и природных ресурсов Ростовской области в 2016 году. Электрон. текстовые дан. - Режим доступа: http:// xn-d1ahaoghbejbc5k.xn-plai/upload/iblock/d09/ vestnik-2.pdf(дата обращения: 02.06.2018). - Загл. с экрана.

10. Постановление правительства Республики Калмыкия «О Стратегии социально-экономического развития Республики Калмыкия до 2020 года» № 465 от 30.12.2008 г. - Электрон. текстовые дан. Режим доступа: http://www.rusouth.info/480981 (дата обращения 28.05.2018). - Загл. с экрана.

11. Постановление законодательного собрания Ростовской области «Об утверждении стратегии социально-экономического развития Ростовской области до 2020 года» № 2067 от 30.10.2007 г. - Электрон. текстовые дан. - Режим доступа: http:// www.donland.ru/default.aspx?pageid $=85416 \# g 1$ (дата обращения: 28.05.2018). - Загл. с экрана.

12. Распоряжение правительства Ставропольского края «Об утверждении стратегии социальноэкономического развития Ставропольского края до 2020 года» № 221-рп от 15.07.2009 г. - Электрон. текстовые дан. - Режим доступа: http://stavinvest.ru/ work/sub21/sub98 (дата обращения: 28.05.2018). Загл. с экрана.

\section{REFERENCES}

1. V Rostovskoy oblasti nablyudaetsya defitsit vodnykh resursov [The Shortage of Water Resources Is Observed in the Rostov Region]. Novosti ministerstva prirodnykh resursov $i$ ekologii
Rostovskoy oblasti [News of the Ministry of Natural Resources and Ecology of the Rostov Region]. URL: http://xn-d 1 ahaoghbejbc5k.xn-p 1 ai/news/vrostovskoy-oblasti-nablyudaetsya-defitsit-vodnykhresursov/.

2. Doklad «O sostoyanii okruzhayushchey sredy Volgogradskoy oblasti v 2016 godu» [Report 'On the State of the Environment of the Volgograd Region in 2016']. Izhevsk, Print-2 Publ., 2017. URL: http://www.ecoindustry.ru/gosdoklad/view/419.html\#.

3. Doklad o sostoyanii okruzhayushchey sredy i prirodopolzovanii v Stavropolskom krae v 2016 godu [Report 'On the State of Environment and Natural Resources in the Stavropol Region in 2016']. Stavropol, 2017. URL: http://www.mpr26.ru /deyatelnost/otchety-doklady/o-sostoyaniiokruzhayushchey-sredy-i-prirodopolzovanii-vstavropolskom-krae/ (accessed 2 June 2018).

4. Doklad o sostoyanii prirodopolzovaniya $i$ ob okhrane okruzhayushchey sredy Krasnodarskogo kraya v 2016 godu [Report 'On the State of Nature Management and Environmental Protection of the Krasnodar Region in 2016']. Krasnodar, 2017. URL: http://www.mprkk.ru/ob-okruzhayuschej-srede/osostoyanii-okruzhayuschej-sredyi/ezhegodnyijdoklad-o-sostoyanii-prirodopolzovaniya-i-ohraneokruzhayuschej-sredyi-krasnodarskogo-kraya/.

5. Doklad ob ekologicheskoy situatsii na territorii Respubliki Kalmykiya v 2016 godu [Report 'On the Environmental Situation in the Republic of Kalmykia in 2016']. Elista, 2017. URL: http:// www.ecoindustry.ru/gosdoklad/view/430.html.

6. Zakon Volgogradskoy oblasti «O strategii sotsialno-ekonomicheskogo razvitiya Volgogradskoy oblasti do 2020 goda» № 1778-OD ot 21.11.2008 g.: prinyat Volgogradskoy oblastnoy Dumoy 30.10.2008 g. [Law of the Volgograd Region 'On the Strategy of SocioEconomic Development of the Volgograd Region till 2020' No. 1778-OD of 21 November 2008: Adopted by the Volgograd Regional Duma on 30 October 2008]. URL: http: //volgoduma.ru/images/stories/files/strategija_2020.pdf.

7. Zakon Krasnodarskogo kraya «O Strategii sotsialno-ekonomicheskogo razvitiya Krasnodarskogo kraya do 2020 goda» № 1465-KZ ot 29.04.2008 g.: prinyat Zakonodatelnym Sobraniem Krasnodarskogo kraya 16.04.2008 g. [Law of the Krasnodar Region 'On the Strategy of Socio-Economic Development of the Krasnodar Region till 2020'No. 1465-KZ of 29 April 2008: Adopted by the Legislative Assembly of the Krasnodar Region on 16April 2008]. URL: http://www.krasnodar.ru/ content/38/show/49460/\#.

8. Matveeva L.G. Gosudarstvennaya komponenta innovatsionnogo potentsiala regionalnoy promyshlennosti [State component of innovative potential of regional industry]. Gosudarstvennoe i munitsipalnoe upravlenie (Uchenye zapiski SKAGS), 2012, no. 2, pp. 32-38. 
9. O sostoyanii okruzhayushchey sredy $i$ prirodnykh resursov Rostovskoy oblasti v 2016 godu [On the State of Environment and Natural Resources of the Rostov Region in 2016]. URL: http://xn-d1 ahaoghbejbc5k. xn-plai/upload/iblock/d09/vestnik-2.pdf.

10. Postanovlenie pravitelstva Respubliki Kalmykiya «O Strategii sotsialno-ekonomicheskogo razvitiya Respubliki Kalmykiya do 2020 goda» № 465 ot $30.12 .2008 \mathrm{~g}$. [Resolution of the Government of the Republic of Kalmykia 'On the Strategy of Socio-Economic Development of the Republic of Kalmykia till 2020' of 30 December 2008 No. 465]. URL: http://www.rusouth.info/480981.

11. Postanovlenie zakonodatelnogo sobraniya Rostovskoy oblasti «Ob utverzhdenii strategii sotsialno-ekonomicheskogo razvitiya Rostovskoy oblasti do 2020 goda» № 2067 ot 30.10.2007 g. [Resolution of the Legislative Assembly of the Rostov Region 'On Approval of the Strategy of SocioEconomic Development of the Rostov Region till 2020' of 30 October 2007 No. 2067]. URL: http:// www.donland.ru/default.aspx?pageid=85416\#g1.

12. Rasporyazhenie pravitelstva Stavropolskogo kraya «Ob utverzhdenii strategii sotsialnoekonomicheskogo razvitiya Stavropolskogo kraya do 2020 goda» № 221-rp ot 15.07.2009 g. [Order of the Government of the Stavropol Region 'On Approval of the Strategy of Socio-Economic Development of the Stavropol Region till 2020' of 15 July 2009 No. 221-rp]. URL: http://stavinvest.ru/work/sub21/sub98.

\section{Information about the Authors}

Natalya A. Kosolapova, Doctor of Sciences (Economics), Professor, Department of Economic Cybernetics, Southern Federal University, M. Gorkogo St., 88, 344006 Rostov-on-Don, Russian Federation, mukazna@yandex.ru.

Ekaterina E. Aydarkina, Candidate of Sciences (Economics), Associate Professor of Department of Information Economics, Southern Federal University, M. Gorkogo St., 88, 344006 Rostov-on-Don, Russian Federation, katusha_ai@mail.ru.

\section{Информация об авторах}

Наталья Алексеевна Косолапова, доктор экономических наук, профессор кафедры экономической кибернетики, Южный федеральный университет, ул. М. Горького, 88, 344006 г. Ростов-на-Дону, Российская Федерация, mukazna@yandex.ru.

Екатерина Евгеньевна Айдаркина, кандидат экономических наук, доцент кафедры информационной экономики, Южный федеральный университет, ул. М. Горького, 88, 344006 г. Ростов-на-Дону, Российская Федерация, katusha_ai@mail.ru. 